\title{
Erratum to: Monitoring Perceptions of Social Progress and Pride of Place in a South African Community
}

\author{
Valerie Møller • Sarah Radloff
}

Published online: 6 April 2011

(C) Springer Science+Business Media B.V./

The International Society for Quality-of-Life Studies (ISQOLS) 2011

\section{Erratum to: Applied Research Quality Life DOI 10.1007/s11482-010-9092-8}

Unfortunately, the following lines were published incorrectly and should appear as shown below.

From Page 57: Satisfaction with life as a whole served as the indicator of well-being at the individual level: 'Taking all things together, how satisfied are you with your life as a whole these days? Generally speaking, would you say you are very satisfied, satisfied, dissatisfied or very dissatisfied?'

From Page 63: Almost a third were for a name change, slightly more than a third thought the name should stay, and just under a third were of the opinion that the name change was unimportant or at least less important than other issues.

The online version of the original article can be found at http://dx.doi.org/10.1007/s11482-010-9092-8.

V. Møller $(\bowtie)$

Institute of Social and Economic Research, Rhodes University, Grahamstown, South Africa e-mail: v.moller@ru.ac.za

S. Radloff

Statistics Department, Rhodes University, Grahamstown, South Africa 